\title{
Retrospective Analysis of Postchemotheraphy Retroperitoneal Lymph Node Dissection (PC-RPLND) Results in Patients with Non-Seminomatous Testicular Cancers
}

\author{
Nonseminomatöz Testis Tümörlü Hastalarda Postkemoterapi \\ Retroperitoneal Lenf Nodu Diseksiyonu (PK-RPLND) Sonuçlarımızın \\ Retrospektif Analizi
}

\author{
Hasan Soydan1, Ercan Malkoç1, Sezgin Okçelik2, Ömer Yılmaz1, Ferhat Ateş1, Furkan Dursun3, \\ Kenan Karademir1, Temuçin Şenkul1
}

1GATA Haydarpasa Teaching Hospital, Clinic of Urology, Istanbul, Turkey

2Beytepe Military Hospital, Clinic of Urology, Ankara, Turkey

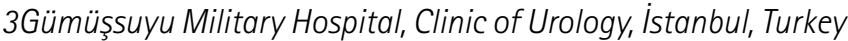

\section{What's known on the subject? and What does the study add?}

Percentage of reduction in mass size, presence of teratom or not in primary tumor and IGCCC risk groups,also local prognostic factors of primary tumor are not predictable of PC-RPLND pathologies.

\begin{abstract}
Objective

Resection of residual masses after chemoteraphy in patients with nonseminomatous testicular cancer is recommended. In our study, we evaluated the patients' data underwent post chemotherapy retroperitoneal lymph node dissection (PC-RPLND).

Materials and Methods

Patients with advanced staged tumors and Non-seminomatous germ cells and having residual mass after chemotherapy whose tumor markers returned to normal were selected in the study. Pre-chemotherapy mass size, postchemoterapy mass size, decrease rate in the mass size, prognostic factors of local tumor, International Germ Cell Collaborative Clasification (IGCCC) risk groups, and teratoma existence in primary pathology, PC-RPLND pathologies were compared for fibrozis, teratoma or viable tumor presence. In addition, patients with and without intraoperative complications were compared in terms of the same parameters. Comparisons were conducted using Statistical Packages for the Social Sciences (SPSS) 16.0 and $p<0.05$ was considered statistically significant.
\end{abstract}

\section{ÖZET}

Amaç

Nonseminomatöz testis tümörlü hastalarda kemoterapi sonrasında artık kitlelerin çıkarılması önerilmektedir. Çalışmamızda Post Kemoterapi Retroperitoneal Lenf Nodu Diseksiyonu (PK-RPLND) yaptığımız hastalarımızın verilerini değerlendirdik.

Gereç ve Yöntem

Nonseminomatöz germ hücreli ileri evre tümörlü hastalardan kemoterapi sonrasında artık kitlesi kalıp, tümör belirteçleri normale dönen hastalar çalışmaya alındı. Kemoterapi öncesindeki kitle boyutu, kemoterapi sonrasındaki kitle boyutu, kitledeki küçülme oranı, lokal tümöre ait prognostik faktörler, IGCCC risk grupları ve primer tümörde teratom olup olmamasına göre PK-RPLND patolojileri fibrozis, terotom ve canlı tümör varlığı bakımından karşılaştırıldı. Ayrıca intraoperatif komplikasyon gelişen ve gelişmeyen hastalar da aynı parametreler bakımından karşılaştıııldı. Karşılaştırma Statistical Packages fort he Social Sciences (SPSS) 16.0 kullanılarak yapıldı ve $p<0,05$ anlamlı olarak kabul edildi.

\section{Correspondence}

Sezgin Okçelik MD, Beytepe Military Hospital, Clinic of Urology, Ankara, Turkey

Phone: +90 2323244543 E-mail: drsezginokcelik@hotmail.com Received: 25.11.2014 Accepted: 01.12.2014 


\begin{abstract}
Results

Twenty six patients were included in the study. Respectively 4 (15\%) viable tumors, $14(54 \%)$ teratoma, $8(31 \%)$ necrosis were observed in patients after PC-RPLND. No significant differences were observed in PC-RPLND pathology results in IGCCC risk groups depending on presence of teratoma in primary tumor or existence of more than $50 \%$ embryonal carcinoma after orchiectomy pathology. Teratoma in 6 of 8 patients with no decrease in the mass rate and viable tumor in 2 patients were detected. More than 90\% reduction rate in the mass was detected in only one patient whose PC-RPLND pathology result was necrosis.There were no significant variations between complication developed and undeveloped patients in terms of mass size and live tumor existence.
\end{abstract}

\section{Conclusion}

Our data is consistent with the current literature. The mass size decrease rate, teratoma presence in orchiectomy material, IGCCC risk groups and local prognostic factors are not accurate predictive factors in determining the PCRPLND pathology.

\section{Key Words}

Testicular cancer, RPLND, postchemotherapy

\section{ÖZET}

\section{Bulgular}

Yirmi altı hasta çalışmaya dahil edildi. PK-RPLND yapılan hastaların sırasıyla 4'ünde (\%15) canlı tümör, 14'ünde (\%54) teratom, 8'inde (\%31) nekroz saptandı. Primer tümörde teratom olması veya olmaması, orşiektomi patolojisinde \%50'den fazla embriyonel karsinom olması, IGCCC risk gruplarına göre PK-RPLND patolojilerinde farklılık saptanmadı. Kitle boyutunda küçülme olmayan 8 hastanın 6'sında teratom, 2'sinde canlı tümör saptandı. Kitle boyutunda \%90'dan fazla küçülme, PK-RPLND patolojisi nekroz olan sadece bir hastada saptandı. Komplikasyon gelişen hastalar ile gelişmeyenler arasında kitle boyutu ve canlı tümör varlığı bakımından farklılık saptanmadı.

\section{Sonuç}

Verilerimiz güncel literatür ile uyumlu olup, kitle boyutundaki azalma oranı, orşiektomi materyalinde teratom olup olmaması, IGCCC risk grupları, ayrıca tümöre ait lokal prognostik faktörler PK-RPLND patolojisini belirlemede öngörücü olmamaktadır.

\section{Anahtar Kelimeler}

Testis tümörü, RPLND, postkemoterapi

\section{Introduction}

Testicular cancer comprises approximately 1-1.5\% of all cancers in men and 5\% of urological tumors. Five cases in 100.000 persons per year is seen in Western countries $(1,2)$. While testicular tumors can be in different histological types, 90-95\% consists of germ cell tumors (2). In clinical staging made after radical orchiectomy of non-seminomatous germ cell testicular tumors, 60-70\% retroperitoneal enlarged lymph nodes are scanned in abdominal computed tomography (CT). While RPLND can be proposed for patients with normal tumor markers in stage $2 \mathrm{~A}$ and in limited stage $2 \mathrm{~B}$ but chemotherapy can be conducted for the same patients. Patients with continous elevating tumor markers and stage $2 \mathrm{C}$ and over are suggested chemotherapy as initial therapy $(3,4)$.

Complete response is seen in 70\% of patients after chemotherapy and mass disappears and tumor markers return to normal (5). Surgery is unnecessary in patients whose tumor markers returned to normal and without metastatic lesions. During the follow-up period relaps occurs in only $3-5 \%$ of these patients (6). In $50 \%$ of patients with the remaining mass, viable tumor cells and teratoma can be observed. If teratoma is left untreated, it may compress adjacent organs by growing slowly and also may transform to secondary cancer by showing malignant transformation at the rate of 3-6\% (7). Surgery is the only treatment option in teratoma due to the chemotherapy resistance. Untreated live cells can grow and metastasize. All detectable residual tumor resection is recommended $(2,3)$.

Despite all improvements in surgical techniques, RPLND, still is a high morbidity surgery. Therefore it is important to select patients with only necrosis for eliminating the need for surgery. Residual tumor size, rate of mass decrease after chemotherapy, teratoma presence in primary orchiectomy specimen, International Germ Cell Collaborative Clasification (IGCCC) risk groups are markers to predict the residual tumor pathology.
In our study, we retrospectively evaluated the data of patients with non-seminotamous testicular cancer after Post Chemotherapy Retroperitoneal Lymph Node Dissection (PC-RPLND), pre-treatment mass size, post-chemotherapy mass decrease and size, local prognostic factors of tumor, IGCCC risk groups, development of complications depending on primary tumor teratoma presence and intended to predict the PC-RPLND pathology.

\section{Material and Methods}

Patients clinically staged as Stage 2 or above with non-seminomatous germ cell tumors and residual masses after chemoteraphy were included in the study. Patients age during diagnosis, tumor side, tumor markers before orchiectomy, orchiectomy pathology, retroperitoneal mass size detected by computerized tomography, mass size after chemoteraphy and decrease in mass size, IGCCC risk groups were all recorded. All the patients whose tumor markers (AFP, beta HCG) turned into normal after chemoteraphy and residual mass, underwent transabdominaly full template RPLND, which surgical borders consisted bilaterally ureters, renal vessels at the top, common iliac vessels crossed by ureters at the bottom. Masses without template were also resected. PC-RPLND pathologies were recorded as teratoma, viable tumor and fibrosis. The variations were compared as RPLND pathology fibrosis and teratoma, viable tumors for primary tumor pathology (teratoma presence, local tumor prognostic factors), tumor size before and after chemoteraphy, mass size decrease rate, IGCCC risk groups. Comparison was made by using Statistical Packages forthe Social Sciences (SPSS) 16.0 and $p<0.05$ was accepted as significant.

\section{Results}

In our clinic, 27 patients underwent PC-RPLND between the years 1996-2012. Twenty six patients with complete data were included in the study. The mean pre-orchiectomy AFP was 1919 (1-17500) ng/ ml, mean beta HCG was 13822 (1.2 to 226.567) mIU/ml. Orchiectomy 
pathology results were mixed germ cell tumor in 20 patients (mght), embryonal carcinoma (EC) in 4 patients and yolk sac tumor in 2 patients. Poor prognostic factors were detected in 11 patients. Prechemoteraphy mean mass size was 69.3 (30-125) mm. While postchemoteraphy mean mass size was $41.2(12-120) \mathrm{mm}$. No decrease in 8 patients' mass size was observed (Table 1).

Live tumor was detected in 4 (15\%), teratoma in 14 (54\%), necrosis in $8(31 \%)$ patients who underwent PC-RPLND. PC-RPLND pathology results of 15 patients whose orchiectomy pathology was without teratoma, 6 patients had teratoma, 7 necrosis, 3 viable tumors. While PC-RPLND pathology of 11 patients whose orchiectomy pathology with teratoma was teratoma in 8 , necrosis in 2 and viable tumor in 1 patients. Teratoma was detected in 3, necrosis in 3, viable tumor in 1 of seven patients whose orchiectomy pathology had EC more than $50 \%$. Necrosis was detected in one patient whose orchiectomy pathology had EC more than 50\% and vascular invasion. Necrosis was diagnosed in one of 2 patients who only had vascular invasion, while teratoma was observed in the other one. Teratoma was detected in 6, viable tumors in 2, necrosis in 1 of nine patients without these risk factors (Table 2). Necrosis in 7, teratoma in 8, viable tumors in 2 was found in 17 good risk group patients according to IGCCC. Teratoma in 2 , live tumors in 1 was observed in 3 intermediate risk group patients. Teratoma in 3, necrosis in 1, viable tumors in 1 seen in 5 poor risk group patients (Table 1).

Teratoma was detected in 6, live tumors in 2 of 8 patients whose mass size didn't decrease. There was only one patient whose mass size decreased more than 90\% and PC-RPLND pathology was necrosis. Two patients underwent metastasectomy surgery for residual mass in lung. One of them had necrosis and the other teratoma.

During the surgery, ureteral avulsion in one patient, renal vein injury in other, vena cava injury in 4 patients were exprienced and primarily repaired. Inferior mesenteric artery was cut because of extreme adherence to mass and no complication was encountered during

Table 1. Clinical and histopathological features of testis tumors

\begin{tabular}{|c|c|c|c|}
\hline & & $n$ & $\%$ \\
\hline \multirow{3}{*}{ Orchiectomy pathology } & EC & 4 & 15 \\
\hline & Yolc sac & 2 & 8 \\
\hline & MGCT & 20 & 77 \\
\hline \multirow{3}{*}{$\begin{array}{l}\text { IGCCC } \\
\text { Tumor risk group }\end{array}$} & Good & 17 & 68 \\
\hline & Intermediate & 3 & 12 \\
\hline & Poor & 5 & 20 \\
\hline \multirow{4}{*}{ Local prognosis factors } & Vascular invasion & 2 & 11 \\
\hline & $\mathrm{EC}$ & 7 & 37 \\
\hline & $\mathrm{VI}+\mathrm{EC}$ & 1 & 5 \\
\hline & No & 9 & 47 \\
\hline \multirow{2}{*}{$\begin{array}{l}\text { Teratoma in primary tumor } \\
\text { pathology }\end{array}$} & Yes & 11 & 42 \\
\hline & No & 15 & 58 \\
\hline \multirow{3}{*}{ Decrease in mass size } & No & 8 & 32 \\
\hline & $<\% 90$ & 16 & 64 \\
\hline & $\geq \% 90$ & 1 & 4 \\
\hline
\end{tabular}

the postoperative period. Anterior branch of the right renal artery was ligated in one patient. Postoperative $70 \%$ renal loss in the same side was detected via renal DMSA scintigraphy. Prolonged lymphatic drainage in 4 patients was resolved with conservative treatment. Partial resection could be conducted in two patients because the mass was too large and extreme adherence to the vena cava. Live tumor cells were detected in these two patients and they died despite of additional chemotherapy. There were no significant differences in post chemoterapy mass size and live tumor rates between the patients with and without complications.

Patients were surveilled for 27 means (3-60) months.

\section{Discussion}

Treatment of residual mass after chemoteraphy in patients with advanced-stage testicular cancer is also a problem due to morbidity along with the difficulty of surgery. Therefore, it is important to find the parameters avoiding the surgery. Because in patients with necrosis and fibrosis, cure is possible after surgery. As in the past studies on PC-RPLND necrosis, teratoma and viable tumor rates were reported as similarly as 30\% (8), in recent studies a decrease in viable tumor detection rate was seen $(9,10,11)$. This depends on the phase shift of testicular tumor and the chemotherapy efficiency. In the recent publications 35-50\% necrosis, 30-60\% teratoma and viable tumor in the remaining was reported $(12,13,14,15,16,17)$. Our data is compatible with the current literature, necrosis, teratoma, and viable cell rates were found as 31\%,54\% and 15\%, respectively.

Studies have been conducted to predict necrosis presence in the residual mass by using such parameters like; the data obtained by imaging methods, characteristics of the primary tumor and response to treatment. In studies investigating the live tumor presence by PETCT 70\% sensitivity, 48\% specificity, 59\% positive predictive value and $51 \%$ negative predictive value was obtained. PET-CT revealed no uptake in patients with teratoma (18). While there are studies arguing that low attenuation levels in CT predict necrosis, but there are also other studies that don't support this idea $(10,19,20)$. Therefore, conclusion was that the results of any imaging and prediction approaches are not

\begin{tabular}{|c|c|c|c|c|}
\hline & & Necrosis & Teratoma & $\begin{array}{l}\text { Viable } \\
\text { tumor }\end{array}$ \\
\hline \multirow[t]{4}{*}{ Local prognosis factors } & $\begin{array}{l}\text { Vascular } \\
\text { invasion }\end{array}$ & 1 & 1 & - \\
\hline & EC & 3 & 3 & 1 \\
\hline & $\mathrm{VI}+\mathrm{EC}$ & 1 & 1 & - \\
\hline & No & 1 & 6 & 2 \\
\hline \multirow[t]{2}{*}{$\begin{array}{l}\text { Teratoma in primary } \\
\text { tumor pathology }\end{array}$} & No & 7 & 6 & 3 \\
\hline & Yes & 2 & 8 & 1 \\
\hline
\end{tabular}

EC: Embrionel carcinoma, VI: Vascular invasion 
sufficient to diagnose a viable tumor. There are also studies that have evaluated the fact whether residual mass size is sufficient for avoiding surgery. In Memorial Sloan-Kettering Cancer Center (MSKCC) study: 3 viable tumors, 5 teratomas were found in 39 patients whose residual mass size smaller than $1.5 \mathrm{~cm}$ (21). In another series consistsing of 87 patients whose masses were smaller than $20 \mathrm{~mm}$, viable tumor in $7 \%$, teratoma in 26\% reported. Whereas in masses less than $5 \mathrm{~mm}$ were reported to be viable tumor (22). In a series of 154 patients in (MSKCC) whose residual mass $1 \mathrm{~cm}$ or smaller; viable tumor in 1\%, teratoma in 22\% (23) were found. PC-RPLND udergone patients with residual mass smaller than $10 \mathrm{~mm}$; teratoma in 11 and viable tumor seen in 1 of the 37 patients (24). Therefore, no safe residual mass size determines that support surgery was unnecessary evaluating tumor presence according to residual mass after chemoteraphy in the studies. In our survey there were 5 cases smaller than $15 \mathrm{~mm}$; necrosis was reported in 3, teratoma in 2 patients. In 7 cases mass size $20 \mathrm{~mm}$ or smaller; teratoma in 3, viable tumor in 1 and necrosis in 3 cases were found.

While IGCCC risk categories can provide predictions regarding survival rates, but in adequate to predict the presence of viable tumor masses. In all risk groups 16\% average residual viable tumor seen (16). In our series, there was no difference in terms of viable tumor detection rates between IGCCC risk groups. In good risk group necrosis in 7 patients, teratoma in 9, viable tumor in 2 patients was detected. In the intermediate-risk group, teratoma in 2 and 1 viable tumor was noted. In poor risk groups 1 necrosis, 2 teratoma and 1 viable tumor was found. Considering the patients according to the presence of pathological poor prognosis factors of the primary tumor, presence or absence of risk factors were unpredictible. Predicting necrosis in residual masses via multivariate analisis by using parameters like; normal tumor markers, increased LDH, small pre-chemotherapy mass size and significant post-chemotherapy decrease, reveals necrosis possibility the accuracy of $70 \%$ or more is seen in $4 \%$ of patients and clinically useless $(25,26,27)$.

Teratoma was found in 67-86\% RPLND pathology of patients whose orchiectomy pathology was teratoma (23). While in the patients without teratoma in the orchiectomy pathology teratoma was found in the RPLND pathology. There are studies that show teratoma absence in the primary pathology can show teratoma absence in the residual mass. Donohue et al. asserted that RPLND is unnessary in patients whose orchiectomy pathology result is without teratoma and tumor markers are normal with more than 90\% decrease in mass (10). However, in the same studies of the group and other groups 26-34\% teratoma presence observed after PC-RPLND in patients whose primary tumor pathology was without teratoma $(6,21,28)$. In our series, in patients with teratoma in the orchiectomy pathology, teratoma presence rate in PC-RPLND was 72\%. The teratoma rate of patients whose orchiectomy pathology without teratoma was 40\%.

No relapse is observed in $80 \%$ of patients whose PC-RPLND pathology results were teratoma.

Viable tumor in 50\%, teratoma in 33\% and malignant transformed teratoma in 17\% were seen in patients with relapse. As the majority of relapses were seen in lungs, retrocrural areas and liver, supports the idea that the teratoma in the retroperitoneum can be curable by surgery (29). Following two additional cycles of chemoteraphy in $70 \%$ of viable tumor detected patients cure is possible after residual mass completely resected. However, recurrence was observed in all those patients that did not undergo chemotherapy and 90\% of those with partial resection (30). In our study, two patients with partial resection died despite of chemotherapy because of progressive disease.

PC-RPLND should be performed as soon as possible after a diagnosis of residual masses. In a study comparing surgery before or after mass progression, early surgery group provides significant advantages of progression and cancer-specific survival (31). Our patients were evaluated after chemotherapy with CT and were operated within fifteen days after the mass was observed.

Classically PC-RPLND is conducted by bilaterally full template technique. Simple excision of masses is unacceptable method. Also modified templates are unsuitable, because there is a possibility of viable tumor existence outside the template. In Wood's study teratoma or viable tumor was found outside the template in $8 \%$ of patients (32). However, there are attempts to reduce the surgery morbidity. There are studies on using modified template because of necrosis detection after intraoperative frozen results, depending on metastases sites, primary tumor's routine metastasis location There are also studies on nerve spared bilateral full template resection $(14,15,33,34)$. Aprikian et al. extracting frozen section from the mass during limited surgery in case of necrosis presence and bileteral full template surgery in case of teratoma or viable tumor. Recurrence was seen $14 \%$ in limited surgery group and $26 \%$ in the full template group no recurrence was noted in retroperitoneal section (35). Similarly Herr made limited RPLND to patients with necrosis in frozen section and 14 relapse was seen during follow up period of six years and only 2 had recurrence has been reported in the retroperitoneum. The possibility of major intraoperative vascular injury during surgery in this manner is indicated to reduce at $80 \%$ rate (33).

Studies on determining surgery limits according size of the residual mass and primary spread area were also conducted. In Indiana University in a series of 100 patients who had $<5 \mathrm{~cm}$ mass in the primary tumor spread area, relapse was noted in 4 patients at the end of the 32 months follow-up period and with limited RPLND and all of them were beyond the bilateral template field (15). Cologne study group divided the mass size into tree group as $\leq 2 \mathrm{~cm}, 2-5 \mathrm{~cm}$, and $>5 \mathrm{~cm}$ and conducted modified RPLND in the 1st group, full template RPLND in the second group who had mass in the interaortocaval area, and modified RPLND for those with paracaval and paraortic, full template RPLND in primary off tumor span patients. Full template RPLND is always conducted for group 3. studies revealed that complications are less significant in the modified groups. At the end of average 4-year follow-up period 3 of 4 recurrences developed in areas outside the full template area, the other recurrence was found intemplate area in one of the patientin modified group. While antegrade ejaculation is preserved in 85\% modified group, but in 75\% loss in full template group (36). Five-year recurrence-free survival rate was $98 \%$ and in nerve preserved PC-RPLND in a study, antegrade ejaculation rates were reported as 79\% (33).

However, although acceptable results, proper patient selection should be emphasized and redo RPLND's survival rates are significantly lower. Moreover, in cases with large residual masses counterparty involvement is $2.6-8 \%$ after full template RPLND $(24,32,37)$. All the 
patients were subjected to bilaterally full template RPLND without nerve sparing.

Various complications can be encountered due to desmoplastic reaction and residual mass location. Stephonson reported 5\% nephrectomy rate in the 650 patients in PC-RPLND series (38). In our series nephrectomy was conducted in any case, but there was significant decrease in ipsilaterally renal function due to the ligation of the anterior branch of the renal artery in one patient. Ureteral avulsion occured in 1 patient and and was urgently repaired Except these two major complications, there wasn't any othe complications requiring additional interventions.

\section{Conclusions}

The results of our study is compatible with the current literature. The decrease rate in mass size, the lack of teratoma in orchiectomy material, IGCCC risk groups, local prognostic factors of tumor are not predictive in determining the pathology of PC-RPLND. These patients should be treated aggressively because of the progressive nature of the disease and may be fatal.

\section{Conflict of interest}

There are no conflicts of interest.

\section{References}

1. Albers P.Testicular cancer:biology,diagnosis and staging In: Osante $S_{\text {, }}$ Richie JP eds. Testicular cancer:International consultation on testicular cancer, Shanghai, China, November 1-5,2009. SIU,2011:p1-24.

2. Stephenson AJ, Gilligan DT.Neoplasms ot the testis.In: WeinAJ et al. eds. Campbell's Urology. 10th ed. Philadelphia Saunders,2012:p 837-870.

3. Zorlu F, Şahin A. [Treatment of advanced NSGCT].Turkiye Klinikleri J Urology-Special Topics 2008;1:74-81.

4. Stephenson AJ, Aprikian AG, Gilligan TD, Oldenburg J, Powles T, Toner $\mathrm{GC}$, et al. Clinical practical guidelines on the management of low stage non-seminomatous germ cell tumours of the testis. In: Osanto S,Richie JP eds. Testicular cancer:International Consultation on Testicular Cancer, Shangai,China,November,1-5,2009, published by SIU,2011,p:43-66.

5. Donohue JP, Leibovitch I, Foster RS, Baniel J, Tognoni P. Integration of surgery and systemic therapy: results and principles of integration. Semin Urol Oncol 1998;16:65-71.

6. Debono DJ, Heilman DK, Einhorn LH, Donohue JP. Decision analysis for avoiding postchemotherapy surgery in patients with disseminated nonseminomatous germ cell tumours. J Clin Oncol 1997;15:1455-1464

7. Logothetis CJ, Samuels ML, Trindade A, Johnson DE. The growing teratoma syndrome. Cancer 1982;50:1629-1635.

8. Donohue JP, Einhorn LH, Williams SD. Cytoreductive surgery for metastatic testis cancer: considerations of timing and extent. J Urol 1980;123:876880

9. Sheinfeld J. The role of adjunctive postchemotherapy surgery for nonseminomatous germ-cell tumors: current concepts and controversies. Semin Urol Oncol 2002;20:262-271.

10. Donohue JP, Rowland RG, Kopecky K, Steidle CP, Geier G, Ney KG, Einhorn L, Williams S, Loehrer P. Correlation of computerized tomographic changes and histological findings in 80 patients having radical retroperitoneal lymph node dissection after chemotherapy for testis cancer. J Urol 1987; 137:1176-1179.

11. Fossa SD, Qvist H, Stenwig AE, Lien HH, Ous S, Giercksky KE. Is postchemotherapy retroperitoneal surgery necessary in patients with nonseminomatous testicular cancer and minimal residual tumor masses? J Clin Oncol 1992;10:569-573.
12. Donohue JP, Roth LM, Zachary JM, Rowland RG, Einhorn LH, Williams SG. Cytoreductive surgery for metastatic testis cancer: tissue analysis of retroperitoneal masses after chemotherapy. J Urol 1982;127:1111-1114.

13. Steiner $H$, Peschel $R$, Bartsch $G$. Retroperitoneal lymph node dissection after chemotherapy for germ cell tumours: is a full bilateral template always necessary? BJU Int 2008;102:310-314.

14. Heidenreich A, Pfister D, Witthuhn R,Thüer D, Albers P. Postchemotherapy retroperitoneal lymph node dissection in advanced testicular cancer: radical or modified template resection. Eur Urol 2008;53:260-272.

15. Beck SD, Foster RS, Bihrle R, Donohue JP, Einhorn LH. Is full bilateral retroperitoneal lymph node dissection always necessary for postchemotherapy residual tumor? Cancer 2007;110:1235-1240.

16. Spiess PE, Brown GA, Pisters LL, Liu P, Tu SM, Evans JG, et al. Viable malignant germ cell tumor in the postchemotherapy retroperitoneal lymph node dissection specimen: can it be predicted using clinical parameters? Cancer 2006; 107: 1503-1510.

17. Steyerberg EW, Vergouwe Y, Keizer HJ, Habbema JD; ReHiT Study Group. Residual mass histology in testicular cancer: development and validation of a clinical prediction rule. Stat Med 2001;20:3847-3859.

18. Oechsle $K$, Hartmann $M$, Brenner W. Venz $S$, Weissbach $L$, Franzius $C$, Kliesch S, Mueller $S$, Krege $S$, Heicappell R, Bares R, Bokemeyer $C$, de Wit M; German Multicenter Positron Emission Tomography Study Group. [18F] Fluorodeoxyglucose positron emission tomography in nonseminomatous germ cell tumors after chemotherapy: the German multicenter positron emission tomography study group. J Clin Oncol 2008;26:5930-5935.

19. Stomper PC, Jochelson MS, Garnick MB, Richie JP. Residual abdominalmasses after chemotherapy for nonseminomatous testicular cancer: correlation of CT and histology. AJR Am J Roentgenol 1985; 145:743-746.

20. Husband JE, Hawkes DJ, Peckham MJ. CT estimations of mean attenuation values and volume in testicular tumors:a comparison with surgical and histologic findings. Radiology 1982;144:553-558.

21. Toner GC, Panicek DM, Heelan RT, Geller NL, Lin SY, Bajorin D, Motzer RJ, Scher HI, Herr HW, Morse MJ, et al. Adjunctive surgery after chemotherapy for nonseminomatous germ cell tumors: recommendations for patient selection. J Clin Oncol 1990;8:1683-1694.

22. Oldenburg J, Alfsen GC, Lien HH, Aass N, Waehre H, Fossa SD. Postchemotherapy retroperitoneal surgery remains necessary in patientswith nonseminomatous testicular cancer and minimal residual tumor masses. J Clin Oncol 2003;21:3310-3317.

23. Carver BS, Bianco FJ, Shayegan B, Vickers A, Motzer RJ, Bosl GJ, Sheinfeld $\mathrm{J}$. Predicting teratoma in the retroperitoneum of men undergoing postchemotherapy retroperitoneal lymph node dissection. J Urol 2006;176:100-104.

24. Fossa SD, Ous S, Lien HH, Stenwig AE. Post-chemotherapy lymph nodehistology in radiologically normal patients with metastatic nonseminomatous testicular cancer. J Urol 1989;141:557-559.

25. Steyerberg EW, Gerl A, Fossa SD, Sleijfer DT, de Wit R, Kirkels WJ. Validity of predictions of residual retroperitoneal mass histology in nonseminomatous testicular cancer. J Clin Oncol 1998;16:269-274.

26. Vergouwe $Y$, Steyerberg EW, deWit R, Roberts JT, Keizer HJ, Collette L, Stenning SP, Habbema JD. External validity of a prediction rule for residual mass histology in testicular cancer: an evaluation for good prognosis patients. Br J Cancer 2003;88:843-847.

27. Vergouwe $Y$, Steyerberg EW, Foster RS, Sleijfer DT, Fossa SD, Gerl A, de Wit $R$, Roberts JT, Habbema JD. Predicting retroperitoneal histology in postchemotherapy testicular germ cell cancer: a model update and multicentre validation with more than 1000 patients. Eur Urol 2007;51:424-432.

28. Loehrer PJ Sr, Hui S, Clark S, Seal M, Einhorn LH, Williams SD, Ulbright T, Mandelbaum I, Rowland R, Donohue JP. Teratoma following cisplatinbased combination chemotherapy for nonseminomatous germ cell tumors: a clinicopathological correlation. J Urol 1986;135:1183-1189. 
29. Carver BS, Shayegan B, Serio A, Motzer RJ, Bosl GJ ,Sheinfeld J. Long-term clinical outcome after postchemotherapy retroperitoneal lymph node dissection in men with residual teratoma. J Clin Oncol 2007;25:10331037.

30. Fox EP, Weathers TD, Williams SD, Loehrer PJ, Ulbright TM, Donohue JP. Outcome analysis for patients with persistent nonteratomatous germ cell tumor in postchemotherapy retroperitoneal lymph node dissections. J Clin Oncol 1993;11:1294-1299.

31. Hendry WF, Norman AR, Dearnaley DP, Fisher C, Nicholls J, Huddart RA Horwich A. Metastatic nonseminomatous germ cell tumors of the testis: results of elective and salvage surgery for patients with residual retroperitoneal masses. Cancer 2002;94:1668-1676.

32. Wood DP, Herr HW, Heller G,Vlamis V, Sogani PC, Motzer RJ, Fair WR, Bosl GJ. Distribution of retroperitoneal metastases after chemotherapy in patients with nonseminomatous germ cell tumors. J Urol 1992;148:18121815.

33. Herr HW. Does necrosis on frozen-section analysis of a mass after chemotherapy justify a limited retroperitoneal resection in patients with advanced testis cancer? Br J Urol 1997;80:653-657.
34. Pettus JA, Carver BS, Masterson T, Stasi J, Sheinfeld J. Preservation of ejaculation in patients undergoing nerve-sparing postchemotherapy retroperitoneal lymph node dissection for metastatic testicular cancer. Urology 2009;73:328-331.

35. Aprikian AG, Herr HW, Bajorin DF, Bosl GJ. Resection of postchemotherapy residual masses and limited retroperitoneal lymphadenectomy in patients with metastatic testicular nonseminomatous germ cell tumors. Cancer 1994;74:1329-1334.

36. Pfister D, Ohlmann CH, Thuer D, Sahi D, Heidenreich A. Post-chemotherapy retroperitoneal resection of residual masses in germ cell cancer with modified template resection. J Urol 2007;177(Suppl):330 (abstract no. 1000).

37. Rabbani F, Goldenberg SL, Gleave ME, Paterson RF, Murray N, Sullivan LD. Retroperitoneal lymphadenectomy for post-chemotherapy residual masses: is a modified dissection and resection of the residual mass sufficient? Br J Urol 1998;81:295-300.

38. Stephenson AJ, Tal R, Sheinfeld J. Adjunctive nephrectomy at postchemotherapy retroperitoneal lymph node dissection for nonseminomatous germ cell testicular cancer. J Urol 2006;176:19961999. 